\title{
GERAKAN AGAMA BARU DI INDONESIA: STUDI ALIRAN KEPERCAYAAN (AGAMA) SUKU DAYAK HINDU BUDHA BUMI SEGANDU INDRAMAYU
}

\author{
Ibnu Farhan \\ IAI Bunga Bangsa Cirebon
}

\begin{abstract}
Abstrak: Indonesia merupakan salah satu negara yang memiliki kemajemukan di berbagai aspek dalam kehidupan masyarakatnya meliputi suku, budaya dan agama. Dalam kasus agama, Negara Indonesia hanya mengakui enam agama resmi, dan sisanya disebut dengan aliran kepercayaan. Kebijakan yang terkesan berpihak ini tentu saja membuat agama yang diakui oleh negara mendominasi kehidupan beragama masyarakat Indonesia. Namun menarik di tengah-tengah dominasi enam agama di atas justru bermunculan beberapa gerakan agama atau kepercayaan baru di masyarakat. Salah satu aliran kepercayaan tersebut bernama Suku Dayak Hindu Budha Bumi Segandu Indramayu. Tentu saja peristiwa ini adalah sesuatu yang menarik sehingga tulisan ini akan mengkaji tentang faktor-faktor yang menyebabkan kemunculan aliran kepercayaan Suku Dayak Hindu Budha Bumi Segandu Indramayu. Tulisan ini juga akan secara ringkas meneliti ajaran-ajaran dari aliran kepercayaan ini sehingga mampu membuat masyarakat tertarik untuk percaya dan mengikuti aliran kepercayaan tersebut.
\end{abstract}

Kata kunci: Gerakan Agama Baru, Suku Dayak Hindu Budha Bumi Segandu Indramayu

\section{A. Pendahuluan}

Indonesia merupakan salah satu negara dengan jumlah penduduk terbanyak di dunia. Saat ini bahwa jumlah penduduk di Indonesia telah mencapai 257, 9 Juta. Jumlah yang kemungkinan akan terus berkembang dalam masa-masa selanjutnya. Selain sebagai salah satu negara dengan jumlah penduduk terbanyak, menarik juga bahwa negara Indonesia memiliki jenis keragaman suku, budaya, bahasa dan agama yang banyak pula. Dari kondisi yang demikian maka sudah tepat bahwa negara Indonesia 
mempunyai simbol atau moto Bhinneka Tunggal Ika, yang berarti berbeda-beda tetap satu.

Keragaman suku, budaya, bahasa dan agama setidaknya dapat dilihat dari laporan oleh Hildred Geertz dalam Indonesian Cultures and Communities yang menyatakan bahwa terdapat lebih dari 300 kelompok etnis di Indonesia yang mempunyai masingmasing identitas budayannya sendiri-sendiri, lebih dari 250 jenis bahasa daerah, agama-agama besar dan juga agama asli Indonesia yang jumlahnya cukup banyak (Faisal Ismail, 2012; XII). Apa yang disampaikan oleh Hildred Geertz sesungguhnya masih dapat dilihat saat ini, meskipun bahwa jumlah itu tentu saja bisa berkurang saat ini.

Di beberapa kota besar kemajemukan itu dapat disaksikan dengan jelas, misalnya bahwa di kota besar seperti Jakarta atau Bandung dapat ditemukan penduduk Indonesia dari beberapa suku seperti Jawa, Sunda, Madura, Batak, Sasak dan sebagainya, yang mempunyai bahasa dan budayanya masing-masing. Begitu pula dalam hal agama dan kepercayaan, bahwa penduduk Indonesia mempunyai agama dan kepercayaannya masing-masing.

Berkaitan dengan hal itu, sampai saat ini setidaknya terdapat beberapa agama besar yang diakui yang kesemuannya berjumlah enam agama, yaitu Islam, Kristen Katolik dan Protestan, Hindu, Budha dan Konghucu. Di samping agama mainstream terdapat pula agama atau kepercayaan asli Indonesia, baik yang muncul sebelum era agama mainstream masuk ke Indonesia, maupun yang tumbuh subur sesudah adanya agama mainstream.

Untuk jenis pertama, di sini dapat disebutkan adalah aliran kepercayaan Kaharingan, yang merupakan salah satu kepercayaan yang diyakini oleh suku Dayak Kalimantan. Aliran kepercayaan yang lain di antaranya adalah Sunda Wiwiitan, yang merupakan kepercayaan yang dianut oleh suku Baduy Banten, aliran kepercayaan Kejawen yang berkembang jauh sebelum Hindu masuk di Jawa, aliran kepercayaan Buhun dan sebagainya. Sedangkan untuk jenis kedua, adalah aliran kepercayaan yang muncul setelah masuknya agama mainstream, yaitu aliran kepercayaan yang biasa disebut oleh agama mainsrteam sebagai aliran sempalan atau aliran sesat. Dalam hal ini dapat disebutkan 
seperti kepercayaan yang dibawa oleh Lia Eden, aliran kepercayaan Gerakan Fajar Nusantara yang dibawa oleh Ahmad Musadeq dan juga yaitu aliran kepercayaan Suku Dayak Hindu Budha Bumi Segandu Losarang Indramayu, yang akan dibahas dalam penelitian ini.

Meskipun dalam kenyataannya bahwa aliran kepercayaan ini kerap mendapatkan perlakuan yang kurang adil baik oleh penganut agama mainstream maupun oleh pemerintah itu sendiri. Namun menarik dilihat di sini bahwa aliran kepercayaan baru ini, tetap mendapatkan tempat dalam masyarakat Indonesia, padahal faktanya bahwa mayoritas masyarakat Indonesia telah menganut agama mainstream.

Salah satu dari contoh tersebut adalah aliran kepercayaan Suku Dayak Losarang di mana pendirinya, Takmad, mengklaim bahwa jumlah penganutnya telah mencapai angka 9000 orang dan tersebar di seluruh Indonesia (Khaerul Umam, 2016; 40). Sebagai perbandingan lain adalah aliran kepercayaan yang belum lama menjadi berita utama di Indonesia, yaitu Gerakan Fajar Nusantara yang rela pindah ke Kalimantan Barat demi mengikuti panutannya Ahmad Musadeq, di mana sudah jelas bahwa sebelum itu Ahmad Musadeq telah difatwa sesat oleh Majelis Ulama Indonesia pusat. Dari hal di atas setiidaknya tidak terallu berlebihan bahwa dapat diambil kesimpulan bahwa aliran kepercayaan baru tersebut di atas mempunyai sesuatu yang menarik sehingga mampu mempengaruhi banyak orang sehingga bergabung ke dalam agama tersebut. Dan peneliti sendiri tidak ragu bahwa perkembangan aliran kepercayaan baru di Indonesia akan terus berlanjut di masa yang akan datang.

Berdasarkan penjelasan di atas, maka penelitian ini akan memfokuskan kajiannya terhadap salah satu bentuk agama atau aliran kepercayaan baru di Indonesia yaitu yaitu aliran kepercayaan Suku Dayak Hindu Budha Bumi Segandu Indramayu. Fokus kajian ini diambil berdasarkan kenyataan bahwa aliran kepercayaan ini masih ada dan diikuti oleh pengikutnya sampai hari ini. Adapun fokus spesifik yang akan dikaji dari aliran kepercayaan ini adalah sejarah dari aliran kepercayaan ini dan ajaran serta doktrinya. Fokus kajian terhadap sejarah dan ajaran diharapkan akan mampu 
memberikan kejelasan mengenai bagaimana dan mengapa muncul aliran kepercayaan ini, apa yang melatar belakanginya dan apa faktor yang membuatnya bisa diterima oleh masyarakat dan mampu beratahan di tengah-tengah tantangan agama mainstream yang ada di Indonesia. Sedangkan fokus kajian terhadap ajaran (doktrin) dari aliran kepercayaan ini diharapkan mampu memberikan informasi mengenai karakteristik dari aliran kepercayaan ini yang membedakannya dengan agama yang lain.

\section{B. Pembahasan}

\section{Gerakan Agama Baru Dalam Kajian Religious Studies}

Dalam bahasa Indonesia agama dipahami sebagai kata yang berasal dari bahasa Sansekerta yang artinya "tidak kacau". Dalam arti yang lengkap, agama adalah peraturan yang mengatur manusia supaya tidak kacau. Terdapat banyak definisi agama yang diterangkan oleh para ahli tentang agama, diantaranya adalah yang disebutkan oleh Anthony F.C. Wallace bahwa agama adalah seperangkat upacara, yang diberi rasionalisasi mitos dan menggerakkan kekuatan-kekuatan supernatural untuk mencapai aatau menghindarkan suatu perubahan keadaan pada manusia atau alam (Dadang Kahmad, 2002; 39). Sedangkan Durkheim mendefinisikan agama sebagai kesatuan sistem keyakinan dan praktik-praktik yang berhubungan dengan suatu yang sacred, yakni segala sesuatu yang terasingkan dan terlarang, keyakinankeyakinan dan praktik yang menyatu dalam suatu komunitas moral yang disebut gereja, di mana semua orang tunduk kepadan-Nya (Peter Connolly, 2011; 20). Bagi Durkheim agama berfungsi sebagai pembangkit perasaan sosial, memberikan simbol dan ritual yang memungkinkan bagi masyarakat untuk mengekspresikan perasaannya yang selalu merasa terikat dengan komunitasnya (Daniel L. Pals, 2012; 167).

Meskipun berbagai definisi agama terkadang bertentangan satu sama lain, tergantung pada sudut pandangnya. C.Y. Glock dan R. Stark (1968; 11-19) membagi lima dimensi yang dapat dikaji dari agama yaitu dimensi keyakinan, dimensi praktek agama, dimensi pengalaman keagamaan, dimensi pengetahuan dan dimensi konsekuensi yang mengacu pada identifikasi akibat 
keyakinan, praktek, pengalaman dan pengetahuan seseorang dari hari ke hari. Sedangkan Joachim Wach membagi tiga wilayah kajian agama yang dapat dikaji yaitu ekspresi pemikiran, ekspresi praktis dan ekspresi persekutuan (Joachim Wach, 1994; 89).

Penelitian mengenai ekspresi pemikiran dimaksudkan untuk mengungkapkan isi kepercayaan dan pengalaman mengenai kepercayaan itu dirumuskan dalam ajaran dan doktrin agama tertentu. Penelitian mengenai hal ini bersifat menyeluruh terhadap semua ajaran yang diyakini oleh penganut agama tertentu. Tidak hanya ajaran yang resmi saja, yang umum saja, namun juga ajaran yang bersifat spesifik. Sedangkan penelitian mengenai ekspresi praktis satu agama berarti mengkaji segala bentuk peribadatan atau ritual yang dilakukan oleh penganut agama tertentu. Baik ritual yang rutin maupun yang tidak rutin. Sedangkan yang terakhir adalah penelitian mengenai ekspresi persekutuan di mana peneliti meneliti bagaimana penganut agama berinteraksi dalam kehidupan sosial.

Agama juga sering difahami sebagai suatu cara pandang dunia atau serangkaian kepercayaan, berkaitan dengan perwujudan dan ungkapan sistem nilai dan jalan hidup dari kepercayaankepercayaan tersebut (John Kelsay, 1994; 7). Dalam sejarah manusia agama telah menjadi bagian yang tak terpisahkan dari manusia. Hal ini dibuktikan bahwa dalam sejarah manusia bahwa manusia pra sejarah sekalipun telah mempunyai agama dengan menganut kepercayaan animimse dan dinamisme. Tidak salah rasanya apa yang dikatakan karen Amstrong bahwa manusia bukan saja homo sapiens namun juga homo religius (Karen Amstrong, 2001; 20). Pantas juga pada dunia manusia yang kita sebut modern bahkan post modern kemudian muncul bentuk-bentuk kepercayaan baru atau kita sebut sebagai gerakan agama baru.

Penamaan terhadap gerakan agama baru pada dasarnya masih menuai banyak perdebatan. Hal ini terutama ketika membahas mengenai kata baru tersebut. Karena pada dasarnya banyak dari beberapa gerakan agama baru bukan fenomena baru dan hanya merupakan kelanjutan dari agama sebelumnya (George D. Chryssides, 2006; 3). Banyak dari gerakan agama baru ini muncul dari agama hindu, kristen bahkan dari agama Islam. Kata 
baru juga sangat sulit untuk dimaknai, ebuah contoh misalnya, apakah agama Yahudi didahului oleh Ibrahim atau Musa? Atau apakah agama Kristen didahului oleh Yahudi? Dan apakah Islam merupakan agama baru yang berasal dari keduanya? Hal ini tidak akan ditemukan jawabanya bila kita hanya melihatnya dari kemunculan agama-agama tersebut. Oleh karena itu butuh prespektif yang lebih luas untuk dapat menyimpulkan sebuah kepercayaan dinamakan sebagai gerakan agama baru.

Dalam kajian sosiologi agama, para pakar biasanya mendefinisikan gerakan agama baru sebagai kata atau istilah yang digunakan untuk merujuk kepada suatu keyakinan keagamaan atau suatu gerakan etis, spiritual atau filsafat yang masih baru yang dari sebuah aliran keagamaan atau lembaga agama yang mapan. Gerakan agama baru berdiri secara independent dan juga mungkin merupakan bagian dari agama-agama yang ada. Istilah GAB mencakup berbagai gerakan yang merentang dari afiliasi kendur berdasarkan pendekatan-pendekatan baru terhadap spiritualitas atau agama hingga upaya-upaya komunitarian yang menuntut konformitas kelompok yang cukup besar serta identitas sosial yang memisahkan para pemeluknya dari masyarakat umum. Sampai saat ini penggunaannya belum diterima secara universal. Beberapa sosiolog menggunakan istilah GAB ini sebagai alternative dari penggunaan kata pemujaan (cult).

Walaupun tidak begitu jelas mengenai definisi GAB tersebut, namun para sarjana biasanya membatasi istilah GAB sebagai kata yang digunakan sebagai agama baru atau agama yang berbeda dari agama yang mapan. Perbedaan dari agama yang mapan ini meliputi keimanan dan pengakuan pengikut GAB atas perbedaan dari agama mapan lainya.

Adapun Sebagai suatu bidang studi ilmiah, studi Agamaagama Baru muncul di Jepang pada awal ledakan inovasi keagamaan setelah Perang Dunia II. Bahkan nama "agama-agama baru" adalah terjemahan langsung dari shin shukyo, yang diciptakan oleh para sosiolog Jepang untuk merujuk pada fenomena ini. Istilah ini kemudian diambil oleh para sarjana Barat pada tahun 1970-an sebagai istilah alternatif untuk menggantikan istilah lama kultus, yang dalam perdebatan tentang kultus pada 
1970-an memperoleh konotasi menghina, dan kemudian digunakan dengan seenaknya oleh para kritikus awam untuk menghina keyakinan-keyakinan yang ajaran-ajarannya dianggap aneh atau sesat.

Sejumlah pakar, khususnya dalam bidang sosiologi agama, menggunakan istilah "gerakan agama baru" untuk melukiskan agama-agama non-arus utama, sementara yang lainnya menggunakan istilah ini untuk merujuk kepada agama-agama yang tidak berbahaya sementara istilah "kultus" untuk kelompokkelompok - baik agama, psikoterapeutik, politik ataupun komersial - yang mereka yakini sangat manipulatif dan eksploitatif.

Dalam penggantian istilah dari kultus atau pemujaan ke gerakan agama baru, para sosiolog sebenarnya tidak sepenuhnya sepakat. Ada beberapa istilah lain yang berkembang selain GAB seperti alternative religious movement (Miller), Emergent religions (Ellwood) dan marginal religious movement (Harper dan Le Beau).

Beberapa GAB dengan pengikut yang luar biasa di Amerika dan Eropa seringkali mengambil praktik-praktik dan ideide yang berasal dari belahan dunia bagian Timur, kebanyakan berasal dari India seperti Brahma Kumaris,Hare Krisna dan Rajneeshism (Osho). Namun ada juga GAB yang tumbuh di Barat yang dikaitkan dengan ajaran-ajaran pimpinan keagamaan atau nabi tertentu seperti Ron Hubbard (Scientology) dan Moses David (Children of God) (Peter Connolly, 2011; 299).

GAB cukup berkembang pesat dan mendapatkan tempat yang baik di Barat. Hal ini setidaknya didukung oleh beberapa faktor yang mendukung berkembangnya GAB di Barat, diantaranya adalah sebagai berikut (Peter Connolly, 2011; 300):

1. Kebutuhan untuk membangun relasi

Para sosiolog mengidentifikasi bahwa GAB banyak berkembang di wilayah perkotaan dimana kaum urban sangatlah tinggi. Karena para urban ini pada masa lalunya terbiasa dengan keadaan desa yang tidak individual, maka dengan sendirinya mereka kemudian merindukan hal tersebut. Hal ini juga karena sudah menjadi kebutuhan manusia untuk 
berupaya bergabung dengan komunitas yang lebih luas agar tidak merasa kesepian.

2. Kekecewaan terhadap sistem sosial modern

Kehidupan modern yang bersifat matrialisme dan konsumerisme kemudian mendorong para penduduk kota besar untuk mencari ketenangan dengan melakukan praktik-praktik meditasi yang diharapkan akan menghasilkan kedamaian pada diri orang tersebut. Kebanyakan juga dari mereka yang tergabung dalam GAB bertujuan untuk memenuhi kebutuhan dan aspirasi emosional, intelektual dan spritual. Dan mungkin juga keinginan untuk hidup dalam keluarga yang lebih luas.

3. Pemimpin GAB yang karismatik

Faktor ini sangat berpengaruh besar dalam perkembangan GAB di Barat. Pemimpin karismatik yang dipandang dapat memberikan solusi kehidupan dunia mampu membawa pengikut yang banyak. Hal ini bisa kita lihat misalnya dalam kasus Ron Hubbard (Scientology) dan Moses David (Children of God), dimana mereka mampu menarik simpati masyarakat bukan saja di negaranya namun juga di belahan dunia yang lain.

Ada beberapa teori yang berkembang yang kemudian menyebabkan seseorang diikuti atau dikultuskan sebagaimana dijelaskan oleh Rodney Stark dan William Sims dalam buku mereka A Theory of Religion (1966; 120). Mereka mengajukan empat teori berkenaan dengan hal ini:

a. The Psycho pathological model, dimana seseorang yang dikultuskan mengalami problem psikologi pada masa lalu, kemudian ia membangun sebuah terapi yang pernah ia lakukan dan menerapkan kepada orang lain.

b. The Entrepreneurial model, dimana seorang yang dikultuskan tersebut berlaku layaknya seorang entrepeneur yang membuat berbagai macam terapi untuk menyelsaikan masalah yang dihadapi orang lain.

c. The Social model, dimana status kultus seseorang dibangun berdasarkan anggapan sosial mengenai dirinya yang dikembangkan oleh pengikutnya kepada masyarakat umum. 
d. The Normal model, dimana status kultus seseorang dibangun berdasarkan kemampuanya menafsikan fenomena supernatural.

Jumlah pengikut GAB memang relatif kecil bila dibandingkan dengan pengikut agama dominan. Akan tetapi, signifikasi relatif mereka dari sudut pandang jumlah dan pengaruh sosial, berkebalikan dengan ulasan media yang luas mengenai GAB atau aktivitas-akitivitas pemujaan.Mengenai kebebesan untuk beragama di Barat memang sepertinya sudah tidak dipermasalahkan lagi. Negara-negara Barat secara umum dikenal sebagai negara yang demokratis dan berkebebasan dalam beragama. Dengan demikian jelas bahwa dalam negara yang demokrasi keberadaan GAB secara hukum dapat berjalan dengan bebas. Namun dalam prakteknya bahwa kebebasan GAB tidak sepenuhnya dapat dirasakan. Beberapa diskriminasi tetap terjadi yang justru dilakukan oleh pemerintah. Sebagai salah satu contoh kasus adalah tragedi Waco di Amerika Serikat. Dengan demikian kesimpulanya bahwa gerakan agama baru masih sering kali mendapat perlakuan yang tidak baik atau diskriminatif baik dari kalangan masyarakat agama dominan atau dari pemerintah itu sendiri. Dalam kasus Indonesia diskriminasi tersebut berbentuk tidak adanya pengakuan kepercayaan secara administratif.

\section{Sejarah Kemunculan Aliran kepercayaan (Agama Baru) Suku Dayak Hindu Budha Bumi Segandu Indramayu}

Nama aliran kepercayaan ini adalah Suku Dayak Hindu Budha Bumi Segandu Indramayu. Penamaan di atas nyatanya memberikan satu keuntungan sendiri dalam hal mendorong kepopuleran aliran kepercayaan ini di Indonesia. Terlebih lagi bahwa simbol-simbol yang diperlihatkan menunjukan bahwa aliran kepercayaan ini adalah salah satu dari bagian dari bentuk kekunoan manusia di tengah modernitas. Tidak heran bahwa rasa penasaran kerap kali muncul ketika melihat sebuah tayangan baik itu gambar atau video yang bercerita tentang aliran kepercayaan ini sehingga membuat banyak orang tergugah untuk mengunjungi mereka. Namun kesan awal yang didapat oleh peneliti ketika berkunjung dan bertemu dengan pendirinya adalah ternyata bahwa apa yang digambarkan selama ini tentang keadaan aliran kepercayaan ini 
tidak seutuhnya benar. Bahwa aliran ini tidak sepenuhnya dikatakan sebagai sebuah aliran yang hidup dalam satu ruang yang jauh dari hingar bingar kemodernan. Namun justru sebaliknya bahwa aliran kepercayaan ini hidup dalam satu ruang sosial yang begitu modern.

Penjelasan tentang nama aliran kepercayaan ini ternyata menunjukan tidak ada hubungannya dengan suku Dayak yang ada di Kalimantan. Kata "suku" yang berarti kaki, yang menunjukan makna bahwa setiap manusia itu berjalan dan berdiri di atas kaki masing-masing untuk mencapai tujuan sesuai dengan kepercayaan dan keyakinan masing-masing. Sedangkan kata dayak berasal dari kata "ayak" atau "ngayak" yang artinya memilih atau menyaring, dalam arti menyaring dan memilah dan memilih mana yang benar dan mana yang salah. "Hindu" artinya kandungan atau rahim. Filosofinya bahwa setiap manusia dilahirkan dari kandungan sang ibu (peerempuan). Sedangkan kata Budha asal dari kata "wuda" yang artinya telanjang, maksudnya setiap manusia dilahirkan dalam keadaan telanjang. Selanjutnya kata "Bumi Segandu Indramayu". "Bumi" mengandung makna wujud, sedangkan "segandu" bermakna sekujur badan. "Bumi Segandu" bermakna sebagai kekuatan hidup. Adapun kata "Indramayu" mengandung pengertian "In" maknanya inti, "darma" artinya orang tua, dan kata "ayu" artinya perempuan. Makna filosofinya bahwa ibu (perempuan) merupakan sumber hidup, karena dari rahimnya-lah kita semua dilahirkan. Itulah sebabnya mereka sangat menghormati kaum perempuan, yang tercermin dalam ajaran dan kehidupan mereka sehari-hari (Nuhrison M. Nuh, 2012; 123).

Aliran Kepercayaan Suku Dayak Hindu Budha Bumi Segandu Indramayu berlokasi di desa Karimun Kec. Losarang Indramayu. Karimun sendiri secara geografis terletak di jalur jalan Pantai Utara Jawa, sehingga akses menuju desa tersebut sangatlah mudah, meskipun letaknya cukup jauh dari pusat pemerintahan Indramayu. Kabupaten Indramayu sendiri merupakan salah satu kabupaten di Jawa Barat. Nama Indramayu berasal dari kata Darma Ayu yang diambil dari nama Nyi Endang Darma yang Ayu yaitu orang kedua pendiri Indramayu. Adapun kondisi wilayah Kabupaten Indramayu sangat diuntungkan secara ekonomis dengan 
letak geografisnya yang berada dialur utama pantura yang merupakan urat nadi perekonomian nasional dan membentang sepanjang pesisir pantai utara pulau Jawa dengan panjang garis pantai $114 \mathrm{~km}$. Luas wilayah Indramayu $204.011 \mathrm{Ha}$ atau 2.040.110 $\mathrm{Km}^{2}$ dengan lahan pertanian yang begitu besar. Hal ini yang membuat Indramayu sebagai salah satu lumbung padi di Jawa Barat. Selain itu yang khas dari Indramayu adalah sebagai penghasil buah mangga, sehingga terkadang Indramayu disebut sebagai kota mangga (Nuhrison M. Nuh, 2012; 123).

Berdasarkan data Kantor Kementerian Agama Kabupaten Indramayu, pada bulan Januari 2010 penduduk Indramayu berjumlah 1.711 .422 orang dengan komposisi pemeluk agama: Islam 1.703 .731 orang, Katolik 2.835 orang, Kristen 4.386 orang, Hindu 160 orang, Buddha 297 orang dan Khonghucu 13 orang, disini tidak ada data tentang jumlah penganut kepercayaan lokal. Sedangkan jumlah tempat peribadatan untuk umat Islam data pada tahun 2008 tercatat sebanyak 761 buah Masjid, 4229 buah Langgar dan 549 buah Musholla. Sedangkan tempat peribadatan untuk pemeluk agama lainnya berupa Gereja berjumlah 19 buah dan Vihara 2 buah. ( Kemenag Kabupaten Indramayu, Data Keagamaan 2010)

Sedangkan dari segi pekerjaan, masyarakat Indramayu begitu beragam mulai dari petani, pedagang dan beberapa pekerjaan lain seperti nelayan dan tentu saja adalah pahlawan devisa negara sebagai Tenaga Kerja Indonesia. Namun begitu berdasarkan kondisi alam yang sedemikian rupa, mayoritas penduduk Indramayu sangan tergantung kepada hasil pertanian. Hal ini juga termasuk pendiri aliran kepercayaan ini, Takmad.

Takmad merupakan pendiri utama Suku Dayak Losarang. Ia merupakan seorang spritualis yang lahir pada tanggal 10 Oktober 1940. Nama asli Takmad adalah Takmad Takmad, namun sebagian sumber menyatakan namanya adalah Paheran Takmad Diningrat, dan biasa dipanggil oleh pengikutnya sebagai Pak Tua. Ia dilahirkan di Malang Semirang, Loh Bener, Indramayu. Sedangkan di desa Karimun di mana ia tinggal sekarang merupakan daerah asal istrinya, Sarini. Saat ini ia bersama dengan istrinya tinggal di desa Karimun beserta lima orang anaknya dan 
juga sebagian pengikutnya yang loyal. Di sana dibangun sebuah padepokan yang diberi nama Padepokan Nyi Ratu Kembar atau Padepokan Bumi Seghandu yang luasnya diperkirakan sekitar $2000 \mathrm{~m}^{2}$, di mana padaepokan itu dikelilingi tembok tinggi dengan ornamen simbol-simbol tokoh pewayangan Jawa (Burhanudin Sanusi, 2015; 30).

Takmad kecil hidup dalam keluarga petani sederhana yang penuh keterbatasan dalam pemenuhan kehidupan sehari-hari. Kondisi ini yang kemudian membuat Takmad sibuk untuk memenuhi kebutuhan hidupnya dibandingkan untuk mengenyam pendidikan. Menurut pengakuannya bahwa Ia hanya bersekolah selama dua tahun di Sekolah Rakyat. Perlu disebutkan di sini bahwa keluarga Takmad, termasuk orang tuannya adalah muslim, namun sekaligus juga penganut ajaran Kejawen. Hal ini setidaknya dibuktikan dengan cerintanya bahwa dalam keluarganya sering diadakan ritual nyuguh (memberi sesajen buat leluhur) pada setiap malam jum'at. Namun begitu secara tegas Takmad mengakui bahwa dirinya pada mulanya adalah muslim, namun sekarang sudah meninggalkan ajaran tersebut. ${ }^{1}$

Tampaknya budaya Jawa atau aliran Kejawen menempati porsi yang khusus dalam mempengaruhi corak ajaran Suku Dayak Losarang. Hal ini setidaknya pada nama-nama yang digunakan untuk Padepokan, atau juga bahwa Takma lebih tertarik menggunakan pewayangan Jawa sebagai metode mengajarkan ajarannya kepada murid-muridnya. Dalam satu kesempatan juga Ia menyatakan bahwa Jawa merupakan suku di mana telah lahir darinya orang-orang yang hebat dan sakti.

Ketika menginjak remaja Takmad tertarik untuk mempelajari ilmu kanuragan dan ilmu kebatinan. Ia mempelajari ilmu tersebut dari seorang bernama Alidan yang berasal dari Banten yang konon darinya Takmad menguasai ilmu menerawang dengan indera ke-enam. Selain itu dalam beberapa catatan disebutkan bahwa guru lain dari Takmad adalah Midun yang berasal dari Aceh. Namun tidak disangkal bahwa Takmad berguru kepada mereka ketika Ia tinggal di daerah Tomang Atas Jakarta

\footnotetext{
${ }^{1}$ Wawancara dengan Takmad pada tanggal 28 Maret 2017, pukul 13.00
} 
Barat. Sumber lain menyatakan bahwa Takmad mewarisi Ilmu Kebatinan dan Kesaktian dari kakeknya Ki Darwi. Pada saat sebelum wafatnya Ki Darwi melakukan ritual pada malam Jum'at Kliwon dengan mengikat dan membungkus Takmad dengan kain kafan yang kemudian dimasukan ke dalam lemari selama tujuh hari (Tarsono, 2014; 38).

Tidak diragukan bahwa Takmad pernah bekerja sebagai kuli di beberapa pelabuhan termasuk di daerah Cilingcing Jakarta Utara sekitar tahun 1960-1970. Di sana Takmad diceritakan sebagai seorang Jawara yang menguasai wilayah tersebut. Namun begitu Takmad dikenal sebagai orang yang baik dalam hal menolong teman-temannya khususnya ketika terjadi gangguan dari makhluk gaib atau juga melakukan pengobatan alternatif. Di tempat ini juga Takmad memulai mengajarkan Ilmunya kepada teman-temannya, dengan memanfaatkan gudang kosong yang berada di sekitar pelabuhan.

Pada tahun 1974, Takmad kemudian kembali ke Indramayu dan memulai perjalannya sebagai seorang Guru. Pada awalnya Takmad mengajar di Silat Serbaguna (SS), yang di dalamnya mengajarkan ilmu kanuragan. SS ini merupakan salah cabang yang diketuai oleh Om Yudon. Ilmu serbaguna yang dipelajari di sini untuk mendapatkan pengasihan, rezeki, pelaris dan untuk mengobati penyakit jasmani dan rohani. Namun ternyata para muridnya yang telah menguasai ilmu tersebut cenderung bersifat sombong sehingga Takmad kemudian membubarkan SS tersebut.

Setelah pembubaran SS Takmad mengisi kehidupannya dengan melakukan pertapaan. Pernah dikabarkan bahwa Takmad melakukan pertapaan di dalam rumahnya selama empat bulan. Dan puncaknya pada tanggal 19 November 1996 dari pertapaan ini kemudian Ia memperoleh satu pencerahan yang memberi kabar bahwa di Indramayu akan terjadi woro-woro atau perang dan banjir darah. Bagi Takmad pencerahan ini dianggap sebagai awal dari lahirnya Sejarah Jawa. Atas hal ini pula kemudian Takmad memberi nama kembali perguruannya dengan sebutan Gelaran Alam (Sejarah adanya manusia). Dari peristiwa ini kemudian Takmad merubah arah perguruannya yang semula merupakan perguruan silat menjadi satu perguruan yang berguru kepada alam. 
Dan setelah sekian lama memperdalam ilmu kebatinannya Takmad pun merasa mendapat pemurnian diri, dari hasil pengkajian ilmu kebatinanya ini, akhirnya menemukan falsafah hidup tentang "kebenaran" yang diyakini dari "Nur Alam" (cahaya alam), yaitu bumi dan langit (Burhanudin Sanusi, 2015; 45).

Pada tahapan selanjutnya perguruan Takmad ini kemudian fokus untuk mengajak anggotanya supaya melaksanakan perbuatan yang benar dan menjauhkan diri dari perbuatan salah, baik terhadap sesama manusia maupun terhadap lingkungan. Perubahan orientasi inilah yang kemudian membuat perguruan Takmad banyak menyedot perhatian masyarakat untuk menjadi pengikutnya. Dan perguruan ini kemudian dikenal dengan sebutan Suku Dayak Hindu Budha Bumi Segandu.

\section{Faktor-Faktor yang Mempengaruhi Kemunculan dan Perkembangan Aliran Kepercayaan Suku Dayak Hindu Budha Bumi Segandhu Indramayu}

Harus ditegaskan di sini bahwa aliran kepercayaan Suku Dayak Hindu Budha Bumi Segandhu merupakan aliran kepercayaan yang independen dalam arti tidak terkait dengan agama apapun yang ada. Secara jelas Takmad menyatakan bahwa Ia tidak menganut agama apapun dan tidak ada hubungan antara agama yang selama ini ada dengan ajaran yang ada dalam aliran kepercayaan ini.

Dari perbincangan panjang lebar dengan Takmad peneliti menyimpulkan bahwa tujuan dari aliran kepercayaan ini adalah untuk memberikan solusi terhadap persoalan kemanusiaan saat ini, dengan cara melakukan hal yang terbaik, mengayomi dan menyantuini siapapun di alam ini. Menurutnya seorang penganut aliran kepercayaan ini harus mampu menjadi penganyom bagi seluruh makhluk yang ada di alam ini baik itu manusia, binatang dan tumbuhan.

Dari hasil pengamatan yang dilakukan peneliti ${ }^{2}$, dapat disimpulkan beberapa hal yang mempengaruhi tumbuh berkembangnya aliran ini, yaitu:

${ }^{2}$ Wawancara dengan Takmad pada tanggal 28 Maret 2017, pukul 13.00 
Pertama, menurut Takmad, agama saat ini tidak mampu memberikan solusi terhadap persoalan kehidupan saat ini. Bahkan menurut Takmad bahwa dalam kasus Indonesia dan dunia, agama menjadi sumber konflik dan persoalan. Para penganut agama merupakan manusia yang paling banyak menyumbangkan persoalan di kehidupan ini. Mereka yang korupsi, berzina, membunuh dan pelaku kejahatan lainnya merupakan orang yang mengaku beragama. Selain itu, menurut Takmad bahwa agama mengajarkan sesuatu yang abstrak seperti kepercayaan terhadap Tuhan, ritual-ritual yang di luar logika manusia, yang menurutnya hal ini tidak memberikan manfaat yang praktis terhadap kehidupan manusia saat ini. Atas hal ini maka Takmad kemudian menolak agama, Ia kemudian memberikan solusi dengan kembali ke alam, menyatu dengan alam.

Kedua, sosok Takmad yang mempunyai karisma tersendiri, sehingga mampu menjadikan orang lain tertarik. Meskipun secara intelektual penulis menilai bahwa Takmad tidak begitu mampu menjelaskan konsep-konsep ajarannya secara jelas, namun kerpribadiannya yang santun dan mengayomi menjadi sesuatu nilai plus tersendiri. Di tengah keadaan sosial dan ekonomi di Indramayu, sosok Takmad yang mengayomi tentu saja bisa menjadi tempat untuk mencurahkan keluh kesah melepaskan berbagai persoalan hidup. Hal ini setidaknya diakui oleh salah satu pengikutnya Sumarno bahwa Ia merasa tenang dengan kehidupannya bersama Takmad meskipun penuh dengan kesederhanaan dengan bergantung kepada hasil pertanian.

Ketiga, ajaran Takmad yang sangat sederhana, dengan tidak banyaknya kewajiban, larangan dan ritual dibandingkan dengan agamaa-agama lain. Inti dari ajaran Takmad sebanarnya adalah Ngaji Rasa, memperlakukan orang lain sebagaimana memperlakukan diri sendiri.

Keempat, bahwa kekecewaan terhadap pemerintah juga mendorong tumbuh berkembangnya pengikut aliran kepercayaan ini. Takmad dan pengikutnya yang loyal secara tegas menhindari semua jenis catatan administrasi pemerintahan. Menurutnya tidak 
ada hal yang bisa bermanfaat dari pemerintahan yang telah lama mengabaikan rakyatnya. Hal ini setidaknya sebagai bentuk protes terhadap kebijakan-kebijakan pemerintahan yang ada.

Kelima, meskipun Takmad tidak mengakui bahwa masih diajarkannya ilmu kebatinan, kesaktian, namun berdasarkan informasi pengikutnya yang penulis temukan di lokasi, bahwa Takmad masih mempraktikan ilmu tersebut ketika beberapa orang atau pengikutnya meminta tolong berkaitan dengan hal gaib, seperti ketika ada yang meminta bantuannya menangani kejadian seperti santet dan sebagainya. Hal ini tentu saja menjadi satu penegasan tersendiri bahwa Takmad merupakan seorang tokoh yang mempunyai ilmu yang lebih dibandingkan orang lain.

\section{Ajaran dan Doktrin Suku Dayak Hindu Budha Bumi Segandu Indramayu}

\section{a) Konsep Tuhan}

Dalam keyakinan aliran kepercayaan ini konsep tentang Tuhan tidak begitu jelas. Meskipun dalam beberapa hasil penelitian menyebutkan tentang Nur Alam yang kemudian diartikan Sang Pencipta, namun dalam kenyataannya berbeda dengan apa yang diakatakan oleh Takmad itu sendiri. Ketika peneliti menanyakan tentang siapa Tuhan yang dipercayai? Takmad menyatakan bahwa tidak ada Tuhan. Alasan yang sering Ia kemukakan bahwa ketiadaan Tuhan karena Tuhan sendiri tidak hadir di dalam kehidupan manusia. Tuhan tidak bisa dilihat manusia dan manusia juga sebenarnya tidak mengakui Tuhan (Takmad, wawancara, 28 Maret 2017).

Takmad lebih suka menyatakan bahwa tidak ada Tuhan, dan yang ada sebenarnya adalah Alam. Kesatuan dengan Alam lebih harus diutamakan daripada kesatuan dengan Tuhan. Alam tampak dan dirasakan oleh manusia dalam kehidupannya sehari-hari. Semua aktifitas manusia berada di Alam dan sangat bergantung dengannya. Sehingga Alam ini yang kemudian harus dirasakan, disatukan dengan manusia. 
Bila menganalisa dari penjelasan dengan Takmad di atas, maka sekilas dapat dilihat adanya kemiripan dengan ajaran Budha yang tidak membicarakan Tuhan. Budha lebih fokus terhadap kehidupan saat ini yang nyata dirasakan daripada membahas konsep Tuhan yang sangat abstrak. Dalam Budha yang terpenting adalah berusaha berbuat sebaik mungkin sehingga akan mendapatkan kehidupan yang baik pula. Budha sebagaimana yang diketahui sangat berpegang teguh pada ajaran tentang Karma dan hukum sebab akibat.

Dengan demikian setidaknya ada dua konsep ketuhanan yang dapat menjelaskan konsepsi Tuhan di dalam aliran kepercayaan ini. Bahwa mungkin saja aliran kepercayaan ini menganut faham ateisme yang berarti tidak percaya terhadap Tuhan. Atau juga bisa termasuk pada kategori Agnostisisme yang berarti bahwa keberadaan Tuhan di luar jangkauan manusia. (Harun Nasution, 2003: 40). Selain itu aliran kepercayaan ini tidak mempercayai tentang siksa kubur dan hari akhir. Bagi mereka bahwa kehidupan manusia akan berhenti setelah kematian dan akan menyatu kembali dengan alam.

\section{b) Ajaran Sejarah Ngaji Rasa}

Salah satu ajaran yang diajarkan oleh Takmad adalah Sejarah Alam Ngaji Rasa. Kata Sejarah didefinisikan sebagai perjalanan hidup manusia (awal, tengah dan akhir). Sementara alam adalah sebuah ruang lingkup kehidupan atau sebuah wadah kehidupan. Adapun makna dari ngaji rasa secara luas adalah tatacara atau pola hidup manusia yang didasari dengan adanya rasa yang sepuas mungkin harus dikaji melalui kajian antara salah dan benar, dan dikaji berdasarkan ucapan dan kenyataan yang sepuas mungkin harus bisa menyatu dan agar bisa menghasilkan sari atau nilai-nilai rasa manusiaswi, tanpa memandang cara hidup, karena pandangan salah belum tentu salahnya, begitu juga pandangan benar belum tentu benarnya (Khaerul Umam, 2016; 41). Oleh karena itu 
prinsip ngaji rasa adalah jangan dulu mempelajari orang lain, tapi pelajarilah diri sendiri antara salah dengan benarnya . Aktualisasi dari ajaran ini adalah dengan cara mempraktikajannya di lingkungan dan keluarga dengan cara mengabdikan diri kepada istri dan anak.. Maka dalam pandangan aliran kepercayaan ini tingkat pencapain spritual seorang penganut adalah ketia Ia sudah berkeluarga dan dikaruniai keturunan.

Sumber dari ajaran ngaji rasa bukan berasal dari kitab suci, aliran kepercayaan atau agama apapun, maupun budaya tertentu. Namun ajaran ini didasarkan kepada hasil dari pemurnian diri dengan mengambil sikap dan prilaku tokoh pewayangan Semar dan Pandawa Lima yang dianggapnya sangat bertanggung jawab terhadap keluarga. Dengan cara pemurnian diri ini maka diharapkan akan menghasilkan satu nulari di dalam manusia yang pada gilirannya akan memahami makna benar dan salah.

Proses pemurnian diri menurut Takad melalui beberapa tahap yang harus dijalani dengan menjauhkan diri dari keramaian dunia dan kesenangan duniawi. Tahaptahap dari pemurnian diri itu digambarkan dalam beberapa tahapan sebagai berikut:

\section{Wedi ---- Sabar ---- Ngaji Rasa ---- Memahami benar-salah}

Pada awalnya, setiap manusia itu wedi (penakut) baik terhadap alam maupun lingkungannya. Oleh karena itu jika ingin selamat, maka manusia harus sabar dan sumerah diri dalam arti berusaha selaras dengan alam tanpa merusak alam. Prinsipnya di sini adalah jangan merusak alam, karena jika itu dilakukan maka alam juga akan marah kepada manusia. Hidup dengan cara bersatu dan selaras dengan alam akan membawa manusia mengenal alam lebih dekat lagi, sehingga Ia mampu merasakan hidup di alam dengan tentram dan tenang karena mendapatkan perlindungan dari alam..

Tahapan ngaji rasa adalah satu tahapan menuju pemurnian diri. Dalam tahap ini manusia juga diharapkan 
untuk mampu mengendalikan diri dari TIGA TA (harta, tahta dan wanita). Bagi penganut yang sudah menikah, suami harus sepenuhnya mengabdikan diri pada keluarga. Suami tidak diperkenankan menghardik, memarahi atau berlaku kasar terhadap istri dan anaknya. Oleh karena itu dalam kasus ini perceraian merupakan pantangan bagi penganut aliran kepercayaan ini. Begitu juga hubungan di luar pernikahan yang dianggap sebagai sebuah perbuatan yang tercela dan tidak bertanggung jawab (Nuhrison $M$. Nuh, 2012; 132).

Selain kepada keluarga, ngaji rasa juga diaplikasikan kepada sesama manusia dan makhluk hidup lainnya. Menolong orang lain semampunya adalah hal yang sangat dianjurkan. Peneliti sendiri menyaksikan bahwa penganut aliran ini tidak pernah menolak mereka yang meminta pertolongan. Termasuk juga adalah meminjamkan sesuatu yang diperlukan oleh orang yang membutuhkan. Bahkan pinjaman tersebut tidak diajarkan untuk ditagih, namun diserahkan kepada peminjam tersebut sesuai dengan kesanggupan dan kesadarannya. Ngaji rasa juga dilakukan dengan cara hidup yang sederhana dengan menjauhi kesenangan duniawi, menghilangkan perasaan dendam, penasaran dan iri kepada orang lain.

Ajaran ngaji rasa dapat dicontohkan misalnya dalam ajaran jangan memukul orang lain, karena diri kita sendiri juga tidak ingin dipukul oleh orang lain. Tidak menipu karena diri kita juga tidak ingin ditipu oleh oang lain. Jika tidak ingin disakiti maka jangan menyakiti orang lain.

\section{c) Ngaula Ning Anak Rabi}

Ajaran yang juga penting bagi aliran kepercayaan ini adalah ngaula ning anak rabi. Ajaran ini pada dasarnya adalah bagian dari pemurnian diri sehingga akan memahami benar-salah. Ajaran ngaula ning anak rabi., bisa dikatakan sebagai salah satu ajaran yang khas dari aliran ini. Posisi perempuan dan anak dalam penganut 
aliran ini sangatlah tinggi. Berbeda dengan berbagai ajaran agama lain yang cenderung mendudukan perempuan lebih rendah dibandingkan laki-laki.

Sementara dalam dalam kebiasaan masyarakat Indonesia pekerjaan rumah tangga dikerjakan oleh perempuan, namun di dalam keluarga penganut aliran kepercayaan ini, semua pekerjaan tersebut dilakukan oleh sang suami. Tugas istri tidak begitu berat, hanya memenuhi kebutuhan biologis suami dan mengasuh anak. Jadi tidak heran bila suami bertanggungjawab secara penuh di dalam rumah tangga, mulai dari mencari nafkah, memasak, mencuci, membersihkan rumah dan tugas lainnya dalam rumah tangga.

Selain begitu juga perlakuan baik juga diterapkan terhadap anak. Semua keinginan anak harus dipenuhi sebisa mungkin. Sesuatu yang salah di mata anak dan istri maka suami harus juga mengikutinya. Begitu juga bila itu dipandang benar oleh anak dan istri maka itu juga menjadi satu kebenaran. Jadi dalam pandangan penganut aliran kepercayaan ini anak dan istri tidak pernah salah (Takmad, wawancara, 28 Maret 2017).

Tujuan dari pengabdian kepada anak dan istri ini sebenarnya untuk membentuk kesabaran dalam diri seorang suami. Ini adalah ujian bagi suami untuk memahami benar dan salah. Jadi ketika istri memarahi suami, maka di sana suami akan memahami kesalahan dan kebenaran tersebut. Selain itu bahwa di sini suami sedang belajar bahwa kebenaran dan kesalahan tidak disarkan pada sifat subjektif dari yang bersangkutan.

Selain alasan di atas, bahwa ada beberapa hal yang disampaikan oleh penganut aliran kepercayaan ini mengenai alasan pengabdian terhadap anak dan istri. Pengabdian suami terhadap istri sesungguhnya karena istri telah memberikan satu yang berharga terhadap suami, sehingga suami harus membalasnya dengan mengabdi kepadanya. Sedangkan terhadap anak, bahwa anak pada dasarnya tidak berkeinginan ada di dunia, namun hal itu 
ada karena kehendar dari bapak dan ibunya, sehingga ketika anak itu sudah ada di dalam kehidupan ini, maka sebagai orang tua harus meyayangi dan memenuhi semua kebutuhannya.

\section{Ritual-Ritual}

Dalam setiap agama maupun aliran kepercayaan sudah dapat dipastikan memiliki ritual-ritual yang bersifat rutin dilakukan oleh para penganutnya. Terdapat beberapa ritual yang dilakukan oleh pengikut aliran kepercayaan ini. Namun tidak ada kewajiban dalam mengikutinya. Kesemuanya dikembalikan kepada masing-masing penganut tergantung kepada kesungguhannya dalam mengamalkan ajaran dari Takmad (Tarsono, 2014; 43). Ritual-ritual itu antara lain:

\section{a) Ritual Kungkum}

Tujuan dari ritual ini adalah melatih kesabaran bagi para penganut aliran kepercayaan ini. Ritual ini dilakukan selama 30 hari berturut-turut. Kungkum sendiri berarti berendam di air. Tempat ritual ini dilakukan di sungai di dekat perguruan. Waktu pelaksanaan ritual kungkum dari pukul 12 malam hingga 6 pagi. Di dalam ritual ini para penganut diharapkan untuk melakukan perenungan tentan kehidupan. Ritual ini termasuk kepada ritual yang dapat meningkatkan status para penganut aliran kepercayan ini menuju tahapan ritual selanjutnya. Selama pelaksaan ini pula mereka hanya memakan makanan yang hanya berasal dari tumbuhan. Hal ini karena tumbuhan tidak termasuk kepada kategori yang mempunyai nyawa.

\section{b) Ritual Pepe}

Di samping ritual kungkum, penganut aliran kepercayaan ini juga melakukan ritual pepe atau berjemur. Ritual ini dilakukan selama 4 bulan berturut-turut dimulai secara bersamaan dengan hari pertama puasanya menurut umat Islam. Ritual ini dianggap sebagai puasanya penganut aliran kepercayaan ini. Ritual pepe adalah kegiatan di pagi hari, menikmati udara pagi dan terik matahari yang dimulai 
dari pukul 09.00-14.00. Ritual ini dilakukan di lapangan padepokan. Posisi awal setiap anggota adalah berdiri dengan membentuk lingkaran dan saling berpegangan sambil membaca pujian. Setelah itu mereka kemudian tidur terlentang dengan posisi masih membentuk lingkaran.

\section{c) Ritual Malam Jumat Kliwon}

Selain dua ritual di atas, saatu ritual lainnya yang penting yang dilakukan oleh aliran kepercayaan ini adalah ritual malam Jumat Kliwon. Ritual ini dilakukan mulai pukul 19.00 dengan diikuti oleh penganut baik itu laki-laki maupun perempuan. Ritual ini dilakukan di tempat khusus di dalam padepokan yang disebut dengan ruang Krakatau di mana di dalamnya terdapat sebuah kolam kecil. Para pelaku ritual kemudian duduk mengelilingi kolam tersebut. Dalam ritual ini juga disajikan bunga tujuh rupa dan tujuh gelas yang berisi berbagai macam minuman seperti air putih, kopi, teh, bajigur dan lain-lain.

\section{d) Ritual Ruatan Putri Keraton}

Salah satu ritual yang dilakukan oleh penganut kepercayaan ini adalah ritual ruatan putri keraton. Ritual ini tampaknya hanya bersifat kondisional karena di berbagai sumber penelitian yang telah ada tidak banyak menyebut tentang ritual ini. Tujuan dari ritual ini adalah sebagai sambung tangan dan sambung rasa persaudaraan antara penganut aliran kepercayaan ini dengan siapapun baik itu individu maupun masyarakat lainnya. Menarik bahwa selain mengundang masyarakat sekitar Desa Karimun, pada acara ini juga diundang berbagai macam aliran kepercayaan yang ada seperti suku Baduy, Komunitas Cigugur, Himpunan Pengawas Kepercayaan dan aliansi Bhineka Tunggal Ika.

Bentuk dari ritual ini pada intinya adalah simbolisasi dari ajaran Takmad. Simbol itu seperti dalam bentuk atraksi reog atau wayang uwong kemudian diisi pula dengan atraksi kebo ngamuk sebagai lambang karakter 
masing-masing manusia. Dalam salah satu sumber dikatakan bahwa ritual ini pernah dilakukan pada tanggal 26 Februari 2009.

\section{Kesimpulan}

Dari uraian di atas dapat diambil beberapa kesimpulan yaitu: pertama, bahwa Aliran Kepercayaan Suku Dayak Hindu Budha Indrmayu merupakan salah satu aliran kepercayaan atau agama yang baru dan mandiri yang berbeda dengan agama atau kepercayaan yang lain. Beberapa hal yang mendukung lahirnya aliran kepercayaan ini adalah kekecewaan terhadap sistem sosial modern, baik kecewa terhadap agama mainstream maupun pemerintah yang tidak mampu membawakan solusi atas persoalan sosial dan ekonomi yang ada di masyarakat. Sehingga hal ini membangun satu kebutuhan untuk membangun relasi antar individu yang tidak percaya terhadap sistem sosial tersebut. selain itu bahwa kepemimpinan Takmad, yang merupakan pendiri dari aliran kepercayaan ini yang dianggap mempunyai karisma tersendiri. Karisma Takmad ini setidaknya muncul melalui dua model yaitu The Enterpreneurial dan The Normal Model. Takmad dianggap mampu memberikan solusi atas persoalan yang dihadapi oleh pemeluk aliran ini, di samping bahwa ia mempunyai kekuatan supernatural yang berbeda dengan yang lainnnya.

Kedua, Inti dan tujuan dari aliran kepercayaan ini adalah bersatu dengan alam sehingga memahami benar dan salah. Aliran ini mempunyai beberapa ajaran, yaitu ngaji rasa, yaitu bagaimana bisa menghidupkan naluri manusia sehingga mampu membedakan antara yang salah dan yang benar. Selain itu ajaran yang pentind dalam aliran kepercayaan ini adalah mengabdi kepada anak dan istri sebagai sebuah ujian mencapai kesabaran. Di dalam aliran kepercayaan ini terdapat beberapa ritual yang dilakukan di antaranya adalah ritual kungkum, ritual pepe dan ritual jumat kliwon. 


\section{DAFTAR PUSTAKA}

Amstrong, Karen. 2001. Sejarah Tuhan. Bandung: Mizan.

Connolly, Petter [ed]. 2011. Aneka Pendekatan Studi Agama, terj. Imam Khoiri. Yogyakarta: LkiS.

George D. Chryssides. 2006z. A Reader in New Religious Movements, London: Continuum.

Iskandar, Asep Deni. Membaca Bahasa Rupa Sastra Visual Gambar Dinding Komunitas Suku Dayak Hindu Budha Bumi Segandu Indrmayu, dalam Jurnal Dewa Ruci, Surakarta; 2010.

Kahmad, Dadang. 2000. Metode Penelitian Agama. Bandung: Pusataka Setia.

Kelsay, John. 1994. Agama dan Hak Asasi Manusia, Indonesia: Interfidei.

Nasution, Harun. 2003. Filsafat Agama. Jakarta: Bulan Bintang Noor, Juliansyah. 2014. Metodologi Penelitian. Jakarta: Kencana.

Nuh, Nuhrison M. 2012. Dinamika Perkembangan Kegamaan Komunitas Dayak Hindu Budha Bumi Segandu di Indramayu Jawa Barat, dalam Dinamika Perkembangan Sistem Kepercayaan Lokal di Indonesia (Ed) Ahmad Syafi Mufid, Jakarta: Badan Litbang dan Diklat Puslitbang Kehidupan Keagamaan Kemenag.

Pals, Daniel L. 2012. Seven Theoris of Religion, Terj. Inyiak Ridwan. Yogyakarta: IRCiSoD.

Sanusi, Burhanudin. 2015. Disolasi Identitas Diri (Negosiasi dan

Dinamika Kontruksi Identitas Komunitas Dayak Hindu Budha Bumi Segandu). Cirebon: IAIN Syekh Nur Jati.

Stark, Rodney \& William Sims. 1996. A Theory of Religion. New Jersey: Rutgers University Press.

Tarsono, Character Building Pada Manusia (Analisis Terhadap Budaya Suku Dayak Losaran Indramayu), dalam Jurnal Psympathic, Jurnal Ilmiah Psikologi, Juni 2014.

Umam, Khaerul, Ngaji Rasa Dalam Pandangan Komnitas Indramayu, dalam Jurnal Wawasan, Januari 2016.

Wawancara dengan Takmad pada Maret 2017 